\title{
Assessing the Effect of Disease Progression on Spirituality
}

\author{
Siddharth Agarwal \\ Saran Ashram Hospital; \\ Siddharth Hospital, \\ Agra, India
}

\author{
Vijai Kumar \\ Saran Ashram Hospital, \\ Agra, India
}

\author{
Preetvanti Singh \\ Dayalbagh Educational \\ Institute; Deemed \\ University, Agra, India
}

\author{
P. K. Saxena \\ Dayalbagh Educational \\ Institute, Agra, India
}

\begin{abstract}
Disease and sufferings lead religious persons nearer to almighty in search of mercy. Not much is known about how to design and disseminate programs of spiritual exercises and spiritual indicators for persons suffering with some disease (sufferers). Research is required to advance the understanding of prioritized internal and external indicators responsible for spiritual awakening among these sufferers. In this paper, an attempt is made to compute OFDP (overall futuristic decision priority) weights to generate spiritual scenarios for spiritual awakening by using MCFDM (multi-criteria futuristic decision-making) methodology. The generated prioritized spiritual scenarios responsible for spiritual awakening among sufferers were then used to assess the effect of some kind of disease (physical problem, suffering, disorder, etc.) on strengthening their religious faith and defining their optimal spiritual trajectories towards ultimate reality. In this research work, a two-phased DRFI (disease-religious faith-interaction) experiment is also designed and developed. The results derived from Phase-I pilot research study based on prioritized spiritual scenarios on 20 male and female sufferers are also presented.
\end{abstract}

Keywords: spiritual awakening, religiosity, linguistic variables, MCFDM (multi-criteria futuristic decision-making)

\section{Introduction}

The word "spirituality" derives from the Latin word "spiritus", which refers to breath, air, or wind. The spirit, thus, is "that which gives life to, or animates a person". Elements of spirituality include spiritual well-being, the spiritual dimension, spiritual needs, the spiritual perspective, and spiritual awareness.

An enduring question that has intrigued researchers and people in general alike is the extent to which spirituality is related to health outcomes. Several excellent reviews have recently been published. Most of these reviews have been limited to church/service attendance as that has been the predictor typically measured in large-scale epidemiological studies. Yet, crisis is a time when people may turn to God. Despite this hypothesis, no one has tested the extent to which an increase in spirituality occurs around a crisis point such as receiving a diagnosis of a disease, or the extent to which changes in spirituality have been predictive of disease course. In addition, most studies on spirituality and health have been conducted in healthy people (most often the elderly) with less attention to people with illness.

Siddharth Agarwal, M.D., Department of Medicine, Saran Ashram Hospital; Siddharth Hospital.

Vijai Kumar, M.D., Department of Medicine, Medical Education and Health Care Practices, Saran Ashram Hospital.

Preetvanti Singh, Ph.D., Faculty of Science, Dayalbagh Educational Institute, Deemed University.

P. K. Saxena, Ph.D., retired professor and dean, Faculty of Engineering, Dayalbagh Educational Institute. 


\section{Literature Survey}

A number of qualitative studies have included questions relating to spiritual development, spiritual emergency and recovery. Hood (1987) conducted qualitative research with 10 subjects who had each experienced an identified spiritual emergency, using in-depth interviews and written documents. Regner (1999) introduced the notion of spiritual emergency, using a case study to outline the difficulties in differential diagnosis when symptoms of mental illness and signs of spiritual awakening occur together. Fallot (2001) analyzed the key religious and spiritual themes in recovery narratives drawn from spiritual discussion groups, trauma recovery groups, and other clinical contexts at community connections, a mental health facility for people diagnosed with severe mental illness. Jacobson (2001) applied the technique of dimensional analysis to 30 recovery narratives in order to discover the uniqueness of the recovery process.

Not much is known about how to design and disseminate programs of spiritual exercises and spiritual indicators for persons suffering with some disease. Research is required to advance the understanding of prioritized internal and external indicators responsible for spiritual awakening among these sufferers.

Galanter, Dermatis, Bunt, Williams, Trujillo, and Steinke (2007) designed a 6-item spirituality self-rating scale to reflect a global measure of spiritual orientation to life, and demonstrated its internal consistency reliability in substance abusers on treatment and in non-substance abusers. Murray, Kendall, Grant, Boyd, Barclay, and Sheikh (2007) identified and compared changes in the psychological, social, and spiritual needs of people with end-stage disease during their last year of life by synthesizing data from two longitudinal, qualitative, and in-depth interview studies investigating the experiences and needs of people with advanced illnesses. The real-life practice of healing cancer in the community as perceived by clients and healers was investigated by Vaghelaa, Robinsonb, Gorec, Peacea, and Lorencb (2007) in a multi-method pilot study. Preand post- changes in perception towards well-being and client experience were assessed by EQ (EuroQol)-5D, MYCaW (measure yourself concerns and well-being), and a client satisfaction tool. Green, Fullilove, and Fullilove (1998) described the process of spiritual awakenings experienced by persons in recovery during their quest for sobriety and concluded that persons in recovery often undergo life altering transformations as a result of embracing a power higher than one's self, that is, a higher power.

Chuengsatiansup (2003) offered an initial understanding towards a cross-paradigm dialogue in the attempt to incorporate spiritual dimensions of life into the process of health impact assessment. Ritt-Olson et al. (2004) investigated the influence of two potentially protective factors — health-as-a-value and spirituality $—$ on monthly alcohol, cigarette, and marijuana use in two multiethnic groups of adolescents varying in risk. Rippentropa, Altmaierb, Chena, Founda, and Keffalaa (2005) studied the relationship between religion/spirituality and physical and mental health in 122 patients with chronic musculoskeletal pain. Kathleen, Litwinczuk, and Carla (2007), Seegers (2007), and Hall (1998) studied and designed various methods to examine the relationship between spirituality, purpose in life, and well-being in samples of HIV (human immunodeficiency virus)-positive men and women. Mann (1998) made a distinction between important interpersonal dynamics, one being psychological in nature and the other spiritual in essence. Schnoll, Harlow, and Brower (2000) examined the relationship between demographic-disease variables, spirituality, and psychosocial adjustment in a heterogeneous sample of patients with cancer. Cooper, Blount, Kaslow, Rothenberg, and Eckman (2001) evaluated the role of spirituality in patients coping with the pain of sickle cell disease. Maupin (2005) believed that health is evidence of Christian behavior and a close relationship with God and felt that the body would be 
free from the disease, if it kept itself in spiritual order.

Spiritual awakening is the profound experiential realizing of one's true nature, from the illusory trance of apparent separation and egoic identification which most beings are involved. It is the realization of one's natural state and one's very true nature that has always been here - the "oneness of being". Experiencing a spiritual awakening is a life changing experience. Once you have a spiritual awakening, your life is likely to change for the better and you will never think the way that you did before. The spiritual awakening of a person is based on internal spiritual indicators which manifest externally as socio-economic, psychological, physiological, and bio-medical parameters. Disease and sufferings lead sufferers nearer to almighty in search of mercy. In this research work, OFDP (overall futuristic decision priority) weights are computed using MCFDM (multi-criteria futuristic decision-making) methodology (Singh, Srivastava, \& Saxena, 1999) to generate spiritual scenarios for spiritual awakening. The generated prioritized spiritual scenarios responsible for spiritual awakening among male and female subjects (religious persons) suffering from some kind of disease were then used to assess the effect of their disease (physical problem, suffering, disorder, etc.) on strengthening their religious faith and defining their optimal spiritual trajectories towards ultimate reality. A DRFI (disease-religious faith-interaction) experiment was also designed and developed.

\section{Materials and Methods}

The study was completed in two phases: Phase I was identification of prioritized spiritual indicators, for generating spiritual scenarios for spiritual awakening using the MCFDM methodology; and Phase II was computation of DRFI index $\left(\mathrm{D}_{\mathrm{r}}\right)$ using linguistic process methodology to assess the effect of disease on spirituality.

\section{MCFDM Methodology}

MCFDM methodology is a systematic futuristic decision priority-ranking tool based on five principles: future-scan, decomposing, clustering, prioritization, and synthesis. It is a multi-disciplinary, multi-dimensional, multi-person, multi-objective, multi-level, and multi-period methodology that consolidates information about tangible and intangible criteria and alternatives in futuristic decision-making process. The methodology is a non-linear framework for carrying and both deductive and inductive iterative futuristic thinking that allows the consideration of several factors at a time, along with a feedback mechanism and numerical trade-off without the use of the syllogism.

\section{Phase I: Generation of Prioritized Spiritual Indicators}

Four members of DM (decision-making) group formulated the problem. The goal of study was to compute overall futuristic decision priority weights $\left(W_{i^{i}}^{f_{L}}\right)$ to generate and select optimal spiritual scenarios for spiritual awakening. The DM selected IF (interdisciplinary futuristic) group consisting of 120 participants and EP (expert) group consisting of 25 experts from different locations of Agra. The current decision plan, for the goal, was generated by the synthesis picture of effective planning for the goal, resulting from prognosis picture and optative picture by OIA (outside-in approach) and IOA (inside-out approach), with the aid of the possible pictures of the future, characterized as a negative picture, a neutral picture, and an optimistic picture. Different CDP (current decision plan) generated by EP group was clustered into a reasonable set of mutually exclusive and encompassing MFDF (multi-futuristic decision factor). Total 22 MFDFs were generated by EP group. These MFDFs were decomposed into a hierarchy of three levels, descending from the overall goal to various 
MFDO (multi-futuristic decision objectives) at the intermediate levels.

Clustered MFDFs were taken into consideration to rate and rank the MFDF using a10-point scale ranging from 1 ("Least important") to 10 ("Very important"). Feedback of IF group was analyzed by DM to derive FFB (futuristic feedback) weights $\left(f_{i}^{n}\right)$ for the MFDF. From these MFDFs and their respective $\left(f_{i}^{n}\right)$, $w_{i^{\prime} j}^{\prime}$ was calculated. Calculated $w_{i^{\wedge} j}^{\prime}$ helped in generating AFRJ (average futuristic relative judgment), matrix (F) which was used in calculating the OFDP (overall futuristic decision priority) weights $W_{i^{i}}^{f_{L}}$ for all $\mathrm{L}$. The calculated OFDP weights $W_{i^{i}}^{f_{L}}$ helped in selecting prioritized spiritual scenarios responsible for spiritual awakening among sufferers (see Figure 1).

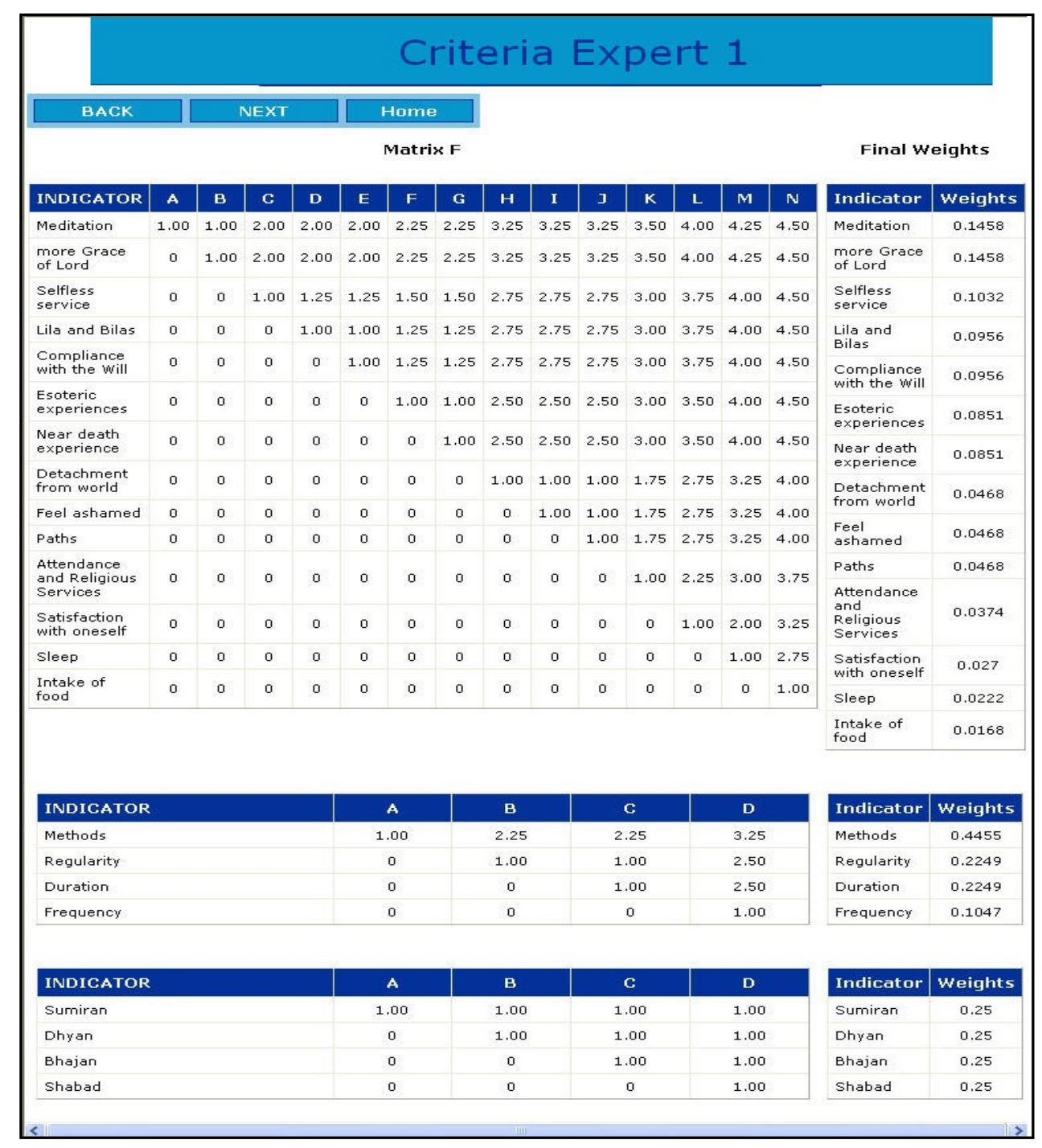

Figure 1. OFDP (overall futuristic decision priority) weights.

\section{Phase II: Computation of $D_{r}$}

A pilot study was conducted on selected sufferers to assess the effect of some kind of disease (physical problem, suffering, disorder, etc.) on strengthening their religious faith and defining their optimal spiritual trajectories towards ultimate reality. This was done on the basis of prioritized spiritual scenarios, generated in 
Phase I. A DRFI index was calculated to measure their spirituality level before and after disease using linguistic process methodology.

The 20 selected male and female subjects of different age groups, suffering from some kind of vital diseases, sufferings, disorders, etc. (cervical spondylosis, lumber spondylosis, chronic digestive problems, respiratory allergies, high cholesterol, high blood pressure, diabetes, coronary heart disease, cancer, peptic ulcer, chronic infections, psychosomatic disorders, etc.) were selected by the research group. Thirteen prioritized spiritual indicators were discussed with the selected sufferers. The selected sufferers were asked to rate and rank these prioritized spiritual indicators based on their before and after disease experience to measure their spirituality using the spiritual linguistic scale (see Table 1). Then the spiritual scores $\left(C_{r_{i}}^{B}\right)$ and $\left(C_{r_{i}}^{A}\right)$ were calculated using:

$$
C_{r_{i}}^{B}=M_{r_{i}}^{B} * R \text { and } C_{r_{i}}^{A}=M_{r_{i}}^{A} * R
$$

where $M_{r_{i}}^{B}$ and $M_{r_{i}}^{A}$ are the spiritual geometric means and $R$ is the random index. From these scores, the $\mathrm{D}_{\mathrm{r}}$ (see Table 2) is computed to assess the effect of disease on spirituality.

Table 1

Spiritual Linguistic Scale

\begin{tabular}{lll}
\hline Linguistic value & Fuzzy scale & Random index \\
\hline Very high & $(9-\delta, 9,9+\delta)$ & 1.0 \\
High & $(7-\delta, 7,7+\delta)$ & 0.8 \\
Medium & $(5-\delta, 5,5+\delta)$ & 0.6 \\
Low & $(3-\delta, 3,3+\delta)$ & 0.4 \\
Very low & $(1,1,3)$ & 0.2 \\
\hline
\end{tabular}

Table 2

DRFI Index (Disease-Religious-Faith-Interaction Index)- $D_{r}$

\begin{tabular}{|l|l|}
\hline$D_{\mathrm{r}}$ & Effect on spirituality \\
\hline $\mathrm{D}_{\mathrm{r}}<1$ & Moderate \\
\hline $1<\mathrm{D}_{\mathrm{r}} \leq 3$ & Highly moderate \\
\hline $3<\mathrm{D}_{\mathrm{r}} \leq 5$ & High \\
\hline $\mathrm{D}_{\mathrm{r}}>5$ & Very high \\
\hline
\end{tabular}

\section{Results and Analysis}

The computation of Phase I was done using criteria expert, a program written in VisualStudio.Net. Figure 1 gives the sample calculation. The generated 22 spiritual indicators along with their $W_{i}^{f_{L}}$ Weights are shown in Figure 2.

Phase II calculations were done using MS excel (see Figure 3) and MatLab. The Phase II study clearly indicates that designed $D_{r}$ is higher after the disease in almost all the cases. The experiences of the selected male and female sufferers revealed that merciful almighty was showering more infinite grace and mercy in their daily worldly and spiritual domains and they were more near to his Holy feet during and after the suffering of the disease. The sufferers revealed that after disease their external love sand faith was strengthened and they continuously remained occupied in internal and external spiritual activities. 


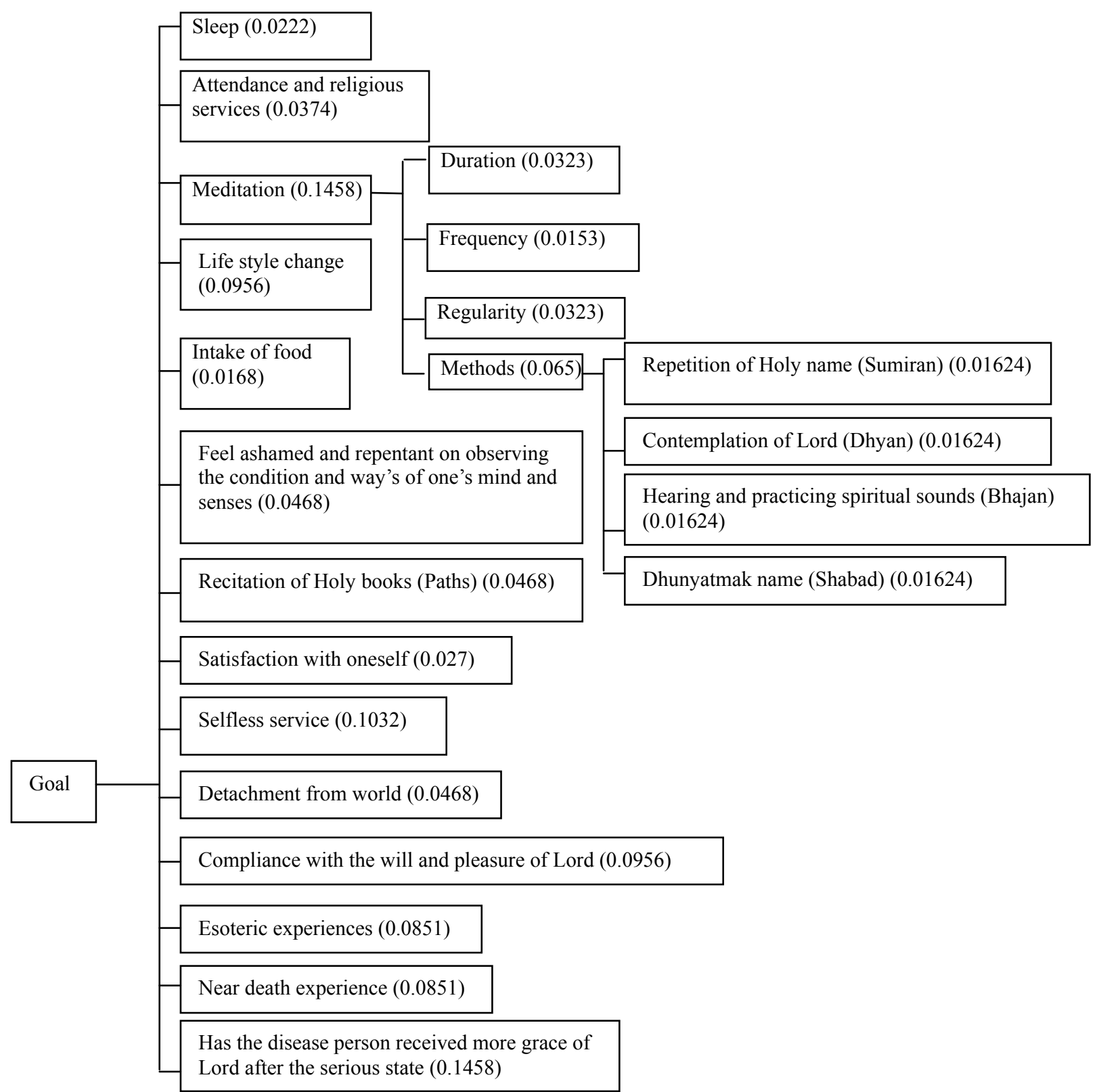

Figure 2. Spiritual indicators with their weights.

\section{Conclusion}

In this research study, selected male and female subjects of different age groups suffering from some kind of disease were asked to assess the effect of their disease (physical problem, suffering, disorder, etc.) on strengthening their religious faith and defining their optimal spiritual trajectories towards ultimate reality on the basis of prioritized spiritual scenarios, generated by computation of $W_{i^{\wedge}}^{f_{L}}$ weights for spiritual awakening by using MCFDM methodology. The study revealed that designed $\mathrm{D}_{\mathrm{r}}$ was higher after the disease in almost all the cases. The selected male and female sufferers were getting more profound grace and mercy in their daily worldly and spiritual activities. This Phase I pilot research study clearly proves that disease and sufferings are boon for the sufferer and an ultimate benefit in terms of spiritual awakening and upliftment. 


\begin{tabular}{|c|c|c|c|c|c|c|c|c|c|c|c|c|c|c|c|c|}
\hline & A & $B$ & C & L & M & $N$ & $\mathrm{P}$ & $Q$ & $\mathrm{R}$ & $S$ & $\mathrm{~T}$ & $\mathrm{AC}$ & $\mathrm{AD}$ & $\mathrm{AE} \mid$ & $\mathrm{AG}$ & Al \\
\hline 1 & \multicolumn{15}{|c|}{ Effect of Disease on Spirituality } & \\
\hline 2 & Patient 1 & & & $\begin{array}{l}\text { Before } \\
\text { Disease }\end{array}$ & \begin{tabular}{|l|} 
After \\
Disease
\end{tabular} & & $\begin{array}{l}\text { Spiritual } \\
\text { Index }\end{array}$ & & Patient 2 & & & $\begin{array}{l}\text { Before } \\
\text { Disease }\end{array}$ & \begin{tabular}{|l|} 
After \\
Disease
\end{tabular} & & $\begin{array}{l}\text { Spiritual } \\
\text { Index }\end{array}$ & \\
\hline 3 & A & M & $\mathrm{H}$ & 2.96 & 5.56 & 2.60 & 3.25 & & & $\mathrm{H}$ & $\mathrm{H}$ & 5.56 & 5.56 & 0.00 & 3.45 & \\
\hline 4 & B & VH & VH & 8.65 & 8.65 & 0.00 & & & 21 & $\mathrm{H}$ & VH & 5.56 & 8.65 & 3.09 & & \\
\hline 5 & $\mathrm{C}$ & $\mathrm{H}$ & VH & 5.56 & 8.65 & 3.09 & & & 31 & M & VH & 2.96 & 8.65 & 5.69 & & \\
\hline 6 & D & M & VH & 2.96 & 8.65 & 5.69 & Spiritualit & & $4 \mathrm{H}$ & $\mathrm{H}$ & VH & 5.56 & 8.65 & 3.09 & Spiritualit & \\
\hline 7 & E & L & VH & 1.15 & 8.65 & 7.50 & HIGH & & 51 & L & $\mathrm{H}$ & 1.15 & 5.56 & 4.41 & HIGH & \\
\hline 8 & F & VL & M & 0.29 & 2.96 & 2.67 & & & 61 & L & M & 1.15 & 2.96 & 1.81 & & \\
\hline 9 & $\mathrm{G}$ & L & VH & 1.15 & 8.65 & 7.50 & & & 71 & L & VH & 1.15 & 8.65 & 7.50 & & \\
\hline 10 & $\mathrm{H}$ & M & $\mathrm{H}$ & 2.96 & 5.56 & 2.60 & & & 81 & M & VH & 2.96 & 8.65 & 5.69 & & \\
\hline 11 & I & VL & M & 0.29 & 2.96 & 2.67 & & & 91 & $\mathrm{M}$ & $\mathrm{H}$ & 2.96 & 5.56 & 2.60 & & \\
\hline 12 & $\mathrm{~J}$ & VL & VL & 0.29 & 0.29 & 0.00 & & & 10 & VL & VL & 0.29 & 0.29 & 0.00 & & \\
\hline 13 & $\mathrm{~K}$ & M & $\mathrm{H}$ & 2.96 & 5.56 & 2.60 & & & 111 & M & $\mathrm{H}$ & 2.96 & 5.56 & 2.60 & & \\
\hline 14 & L & M & VL & 2.96 & 0.29 & 2.67 & & & $12 \mathrm{I}$ & $\mathrm{H}$ & VL & 5.56 & 0.29 & 5.27 & & \\
\hline 15 & $\mathrm{M}$ & M & $\mathrm{H}$ & 2.96 & 5.56 & 2.60 & & & 131 & $\mathrm{H}$ & $\mathrm{VH}$ & 5.56 & 8.65 & 3.09 & & \\
\hline \multirow{2}{*}{\multicolumn{17}{|c|}{$\begin{array}{l}16 \\
18\end{array}$}} \\
\hline & & & & & & & & & & & & & & & & \\
\hline 19 & Patient 3 & & & \begin{tabular}{|l|} 
Before \\
Disease
\end{tabular} & $\begin{array}{l}\text { After } \\
\text { Disease }\end{array}$ & & $\begin{array}{l}\text { Spiritual } \\
\text { Index }\end{array}$ & & Patient 4 & & & $\begin{array}{l}\text { Before } \\
\text { Disease }\end{array}$ & $\begin{array}{l}\text { After } \\
\text { Disease }\end{array}$ & & $\begin{array}{l}\text { Spiritual } \\
\text { Index }\end{array}$ & \\
\hline 20 & 1 & $\mathrm{H}$ & $\mathrm{H}$ & 5.56 & 5.56 & 0.00 & 3.08 & & 11 & L & $\mathrm{H}$ & 1.15 & 5.56 & 4.41 & 3.21 & \\
\hline 21 & 2 & VH & VH & 8.65 & 8.65 & 0.00 & & & 21 & M & $\mathrm{H}$ & 2.96 & 5.56 & 2.60 & & \\
\hline 22 & 3 & $\mathrm{VH}$ & vH & 8.65 & 8.65 & 0.00 & & & 31 & M & $\mathrm{H}$ & 2.96 & 5.56 & 2.60 & & \\
\hline 23 & 4 & $\mathrm{H}$ & VH & 5.56 & 8.65 & 3.09 & & & $4 \mathrm{I}$ & $\mathrm{L}$ & $\mathrm{H}$ & 1.15 & 5.56 & 4.41 & & \\
\hline 24 & 5 & $\mathrm{~L}$ & vH & 1.15 & 8.65 & 7.50 & \multicolumn{2}{|c|}{ Spirituality } & 51 & L & $\mathrm{H}$ & 1.15 & 5.56 & 4.41 & \multicolumn{2}{|c|}{ Spirituality } \\
\hline 25 & 6 & L & $\mathrm{H}$ & 1.15 & 5.56 & 4.41 & HIGH & & 61 & L & $\mathrm{H}$ & 1.15 & 5.56 & 4.41 & HIGH & \\
\hline 26 & 7 & $\mathrm{H}$ & VH & 5.56 & 8.65 & 3.09 & & & 71 & L & $\mathrm{M}$ & 1.15 & 2.96 & 1.81 & & \\
\hline 27 & 8 & vH & VH & 8.65 & 8.65 & 0.00 & & & 81 & L & $\mathrm{H}$ & 1.15 & 5.56 & 4.41 & & \\
\hline 28 & 9 & $\mathrm{H}$ & VH & 5.56 & 8.65 & 3.09 & & & 91 & M & $\mathrm{H}$ & 2.96 & 5.56 & 2.60 & & \\
\hline 29 & 10 & VL & $\mathrm{H}$ & 0.29 & 5.56 & 5.27 & & & 10 & VL & VL & 0.29 & 0.29 & 0.00 & & \\
\hline 30 & 11 & M & VH & 2.96 & 8.65 & 5.69 & & & $11 \mathrm{I}$ & $\mathrm{H}$ & $\mathrm{vH}$ & 5.56 & 8.65 & 3.09 & & \\
\hline 31 & 12 & $\mathrm{H}$ & VL & 5.56 & 0.29 & 5.27 & & & $12 \mathrm{l}$ & $\mathrm{H}$ & M & 5.56 & 2.96 & 2.60 & & \\
\hline 32 & 13 & M & $\mathrm{H}$ & 2.96 & 5.56 & 2.60 & & & $13 \mathrm{I}$ & L & $\mathrm{H}$ & 1.15 & 5.56 & 4.41 & & \\
\hline \multirow{2}{*}{\multicolumn{17}{|c|}{$\begin{array}{l}34 \\
35\end{array}$}} \\
\hline & & & & & & & & & & & & & & & & \\
\hline 36 & Patient 5 & & & \begin{tabular}{|l} 
Before \\
Disease
\end{tabular} & $\begin{array}{l}\text { After } \\
\text { Disease }\end{array}$ & & $\begin{array}{l}\text { Spiritual } \\
\text { Index }\end{array}$ & & Patient 6 & & & $\begin{array}{l}\text { Before } \\
\text { Disease }\end{array}$ & \begin{tabular}{|l|} 
After \\
Disease
\end{tabular} & & $\begin{array}{l}\text { Spiritual } \\
\text { Index }\end{array}$ & \\
\hline 37 & 1 & M & $\mathrm{H}$ & 2.96 & 5.56 & 2.60 & 3.43 & & $1 \mathrm{I}$ & L & $\mathrm{VH}$ & 1.15 & 8.65 & 7.50 & 4.55 & \\
\hline 38 & 2 & L & VH & 1.15 & 8.65 & 7.50 & & & 2 & VL & $\mathrm{M}$ & 0.29 & 2.96 & 2.67 & & \\
\hline 39 & 3 & VL & $\mathrm{M}$ & 0.29 & 2.96 & 2.67 & & & $3 r$ & VL & M & 0.29 & 2.96 & 2.67 & & \\
\hline 40 & 4 & $\mathrm{~L}$ & M & 1.15 & 2.96 & 1.81 & & & 41 & $\mathrm{~L}$ & $\mathrm{M}$ & 1.15 & 2.96 & 1.81 & & \\
\hline 41 & 5 & $\mathrm{~L}$ & $\mathrm{H}$ & 1.15 & 5.56 & 4.41 & \multicolumn{2}{|c|}{ Spirituality } & 51 & L & $\mathrm{vH}$ & 1.15 & 8.65 & 7.50 & \multicolumn{2}{|c|}{ Spirituality } \\
\hline 42 & 6 & VL & M & 0.29 & 2.96 & 2.67 & HIGH & & 61 & M & $\mathrm{H}$ & 2.96 & 5.56 & 2.60 & HIGH & \\
\hline 43 & 7 & VL & M & 0.29 & 2.96 & 2.67 & & & 71 & L & $\mathrm{H}$ & 1.15 & 5.56 & 4.41 & & \\
\hline 44 & 8 & VL & $\mathrm{H}$ & 0.29 & 5.56 & 5.27 & & & 81 & L & VH & 1.15 & 8.65 & 7.50 & & \\
\hline 45 & 9 & VL & $\mathrm{M}$ & 0.29 & 2.96 & 2.67 & & & 91 & L & M & 1.15 & 2.96 & 1.81 & & \\
\hline 46 & 10 & VL & L & 0.29 & 1.15 & 0.87 & & & 10 & VL & $\mathrm{H}$ & 0.29 & 5.56 & 5.27 & & \\
\hline 47 & 11 & M & $\mathrm{H}$ & 2.96 & 5.56 & 2.60 & & & 11 & VL & VH & 0.29 & 8.65 & 8.37 & & \\
\hline 48 & 12 & $\mathrm{H}$ & L & 5.56 & 1.15 & 4.41 & & & $12 \mathrm{I}$ & $\mathrm{H}$ & L & 5.56 & 1.15 & 4.41 & & \\
\hline 49 & 13 & $\mathrm{~L}$ & $\mathrm{H}$ & 1.15 & 5.56 & 4.41 & & & 131 & M & $\mathrm{H}$ & 2.96 & 5.56 & 2.60 & & \\
\hline
\end{tabular}

Figure 3. Phase-II calculations of $\mathrm{D}_{\mathrm{r}}$ before and after the disease.

\section{References}

Chuengsatiansup, K. (2003). Spirituality and health: An initial proposal to incorporate spiritual health in health impact assessment. Environmental Impact Assessment Review, 23, 3-15.

Cooper, E. M., Blount, W., Kaslow, N., Rothenberg, R., \& Eckman, J. (2001). Role of spirituality in patients with sickle cell disease. The Journal of the American Board of Family Practice, 14, 2116-2122.

Fallot, R. D. (2001). Spirituality and religion in psychiatric rehabilitation and recovery from mental illness. International Review of Psychiatry, 13(2), 110-116.

Galanter, M., Dermatis, H., Bunt, G., Williams, C., Trujillo, M., \& Steinke, P. (2007). Assessment of spirituality and its relevance to addiction treatment. Journal of Substance Abuse Treatment, 33, 257-264.

Green, L. L., Fullilove, M. T., \& Fullilove, R. E. (1998). Stories of spiritual awakening the nature of spirituality in recovery. Journal of Substance Abuse Treatment, 15(4), 325-331.

Hall, B. A. (1998). In patients with symptomatic HIV disease, spirituality emerged from stigmatization and having an incurable disease. Res. Nurs. Health, 21, 143-153.

Hood, B. L. (1987). Spiritual emergencies: Understanding transpersonal crises University Massachusetts. Retrieved from http://www.cfidsreport.com 
Jacobson, N. (2001). Experiencing recovery: A dimensional analysis of recovery narratives. Psychiatric Rehabilitation Journal, 24, 248-256.

Kathleen, M., Litwinczuk, B. C., \& Carla, J. G. (2007). The relationship between spirituality, purpose in life, and well-being in HIV-positive persons. Journal of the Association of Nurses in Aids Care, 18(3), 13-22.

Mann, R. L. (1998). A process of spiritual awakening. Retrieved from http://skdesigns.com

Maupin, C. (2005). Spiritual value and chronic illness-part I. Retrieved from http:// www.cfidsreport.com

Murray, S. A., Kendall, M., Grant, E., Boyd, K., Barclay, S., \& Sheikh, A. (2007). Patterns of social, psychological, and spiritual decline toward the end of life in lung cancer and heart failure. Journal of Pain and Symptom Management, 34(4), $393-402$.

Regner, V. A. (1999). Re-examining Christian conversion experiences: Considering Kundalini awakenings and spiritual emergencies (Doctoral dissertation, School of Theology at Claremont).

Rippentropa, A. E., Altmaierb, E. M., Chena, J. J., Founda, E. M., \& Keffalaa, V. J. (2005). The relationship between religion/spirituality and physical health, mental health, and pain in a chronic pain population. Pain, 116, 311-321.

Ritt-Olson, A., Milam, J., Unger, J. B., Trinidad, D., Teran, L., Dent, C. W., \& Sussman, S. (2004). Use among adolescents varying in risk. Journal of Adolescent Health, 34, 192-199.

Schnoll, R. A., Harlow, L. L., \& Brower, L. (2000). Spirituality, demographic and disease factors, and adjustment to cancer. Cancer Pract, 8(6), 298-304.

Seegers, D. L. (2007). Spiritual and religious experiences of gay men with HIV illness. Journal of the Association of Nurses in Aids Care, 18(3), 5-12.

Singh, P., Srivastava, C. N., \& Saxena, P. K. (1999). Futuristic decision priorities to eradicate tribal oncological population by the year 2020 AD. Advances in Biosciences, 18(1), 15-22.

Vaghelaa, C., Robinsonb, N., Gorec, J., Peacea, B., \& Lorencb, A. (2007). Evaluating healing for cancer in a community setting from the perspective of clients and healers: A pilot study complementary. Therapies in Clinical Practice, 13, $240-249$. 